\title{
A novel antifungal protein of Bacillus subtilis B25
}

\author{
Zhiqiong Tan, Baoying Lin and Rongyi Zhang*
}

\begin{abstract}
Bacillus subtilis B25 was isolated from banana rhizosphere soil. It has been confirmed for B25 to have stronger antagonism against Fusarium oxysporum f.sp.cubense, Additionally B25 has good inhibitory to plant pathogens, including Corynespora cassiicola, Alternaria solani, Botrytis cinerea and Colletotrichum gloeosporioides on potato dextrose agar (PDA) plates. The antagonistic substance can be extracted from cell-free culture broth supernatants by $70 \%(\mathrm{w} / \mathrm{v})(\mathrm{NH} 4) 2 \mathrm{SO} 4$ saturation. Clear blank band was observed between the protein and a pathogen. The examination of antagonistic mechanism under light microscope showed that the antifungal protein of B25 appeared to inhibit pathogens by leading to mycelium and spores tumescence, distortion, abnormality. The isolation procedure comprised ion exchange chromatography on DEAE-Sephadex Fast Flow and gel filtration chromatography on SephadexG-100. The purified antifungal fraction showed a single band in sodium dodecyl sulfate-polyacrylamide gel electrophoresis (SDS-PAGE). The active fraction was identified by NanoLC-ESI-MS/MS The amino acid sequences of 17 peptides segments were obtained. The analysis of the protein suggested that it was a hypothetical protein (gi154685475), with a relative molecular mass of 38708.67 Da and isoelectric point (pl) of 5.63.
\end{abstract}

Keywords: Bacillus subtilis; Antifungal protein; Purification

\section{Introduction}

Fusarium wilt, caused by Fusarium oxysporum f.sp. cubense (FOC.), was a devastating disease of banana, which was threatening the safety of banana production in China and the worldwide. At present, this disease have spread to a very large of area. Effective control methods for it are not available. Banana as one of the most important economic crops, its contribution to the overall fruit production reached a very high level, but now many existing banana orchard is being wiped out. It was a potential measure to screen antagonistic bacteria and produce microbial germicide in the control of Fusarium wilt of banana. The chemical control and use of fungicides are the most effective way of preventing the occurrence of plant diseases. However, the use of chemicals is considered undesirable because of concerns over residues, following an increased public health concern. The bio control has become an interesting alternative to conventional methods.

B.subtilis, which distribute in the nature widely as non-pathogenic bacteria, can nonribosomally synthesizes

\footnotetext{
* Correspondence: zryi2013@163.com
Key Laboratory of Protection and Development Utilization of Tropical Crop

* Correspondence: zryi2013@163.com
Key Laboratory of Protection and Development Utilization of Tropical Crop Germplasm Resources, Hainan University, 58\#, Renmin road, 570228 Haikou, Hainan Province, China
}

several kinds of small antibiotic peptides $(<2000 \mathrm{Da})$ that have antifungal activities, such as iturin (Delcambe et al. 1977; Tsuge et al. 2001; Stein 2005), surfactin (Peypoux et al. 1999; Carrillo et al. 2003), fengymycin, bacilysin (Loeffler et al. 1986), bacillomycin (Peypoux et al. 1980), mycosubtilin (Peypoux et al. 1986), and mycobacillin (Sengupta et al. 1971). Additionally B. subtilis secretes an abundance of proteins (Liu et al. 2007; Chen et al. 2010; Luo et al. 2013).

Bacillus subtilis B25 was isolated from banana rhizosphere soil in Hainan. It has been confirmed for B25 that antagonism against Fusarium oxysporum f.sp.cubense (FOC) and other plant fungal pathogen can be produced (Liu 2011, China). We found that the antimicrobial substance could tolerate acid and not changed significantly even in $100^{\circ} \mathrm{C}$ boil 1 hour (Lin 2013, China). The aim of this paper was to extract the antifungal substances of Bacillus subtilis B25 and test it's activity.

\section{Materials and methods Chemicals}

All chemicals were analytical grade. Bovine serum albumin was from Sigma. Low-molecular weight protein standards were purchased from TaKaRa Biotechnology (Dalin) Co., 
Ltd. (China), DEAE-Sephadex Fast Flow was obtained from GE, SephadexG-100 from Pharmacia.

\section{Microorganisms and culture conditions}

B. subtilis B25 was grown in fermentation medium containing (g/L): glucose, 8.0; peptone, 8.0; yeast extract, 1.0; beef extract, 3.0; $\mathrm{NaCl}, 10.0$; The $\mathrm{pH}$ of the medium was adjusted to 7.0 before autoclaving.

Cultivation was performed using $250 \mathrm{ml}$ Erlenmeyer flasks containing $100 \mathrm{ml}$ medium for $48 \mathrm{~h}$ at $28^{\circ} \mathrm{C}$. As inoculation, 2\% (v/v) bacteria grew in Luria-Bertani broth $(\mathrm{g} / \mathrm{L})$ : peptone, 10.0; yeast extract, 5.0; and $\mathrm{NaCl}$, 10.0; $\mathrm{pH} 7.0$.

Fusarium oxysporum f.sp.cubense was isolated from wilted banana vascular and stored at $4^{\circ} \mathrm{C}$ in PDA and it was used as the indicator.

B25 was isolated from banana rhizosphere soil and identified as Bacillus subtilis on the basis of its morphological, biochemical and physiological characteristics, and 16S r DNA sequence. It's capability of controlling Fusarium wilt in green house and in the field was evaluated (Liu et. al. 2011). Also, the characteristics of the active substance, such as precipitated quality, molecular mass, heat-tolerance were test (Lin et. al. 2013).

\section{Assay of of antifungal activity}

B25 was assayed for its antagonistic activity in vitro against Fusarium oxysporum f.sp.cubense, Corynespora cassiicola, Alternaria solani, Botrytis cinerea, Colleto trichum gloeosporioides and Aspergillus niger via duel culture method. A fungal disc of five day old mycelial mat of $1 \mathrm{~cm}$ diameter was placed in the centre of the petri plate containing PDA (potato dextrose agar). And the $24 \mathrm{hr}$ old Bacillus B25 culture was single streaked at a distance of approx. $3 \mathrm{~cm}$ from the fungal disc. The plate was incubated at $28^{\circ} \mathrm{C}$ and observed after every 24 hrs for any inhibition of mycelial growth.

The antifungal activity against FOC of precipitated protein and all fractions acquired in the procedure of separation was tested by agar-diffusion method. A fungal disc was placed in the centre of PDA. Plate. Wells of $0.5 \mathrm{~cm}$ diameter were made at a distance of approx. $3 \mathrm{~cm}$ from the fungal disc. And tested substances were discharged in the wells. The Plate was incubated at $28^{\circ} \mathrm{C}$ and observed for any inhibition of mycelial growth.

\section{Production and purification of antibiotics}

A loop of B25 cells from a slant culture of fresh nutrient agar was inoculated to a $250 \mathrm{ml}$ flask containing $100 \mathrm{ml}$ LB broth ( $\mathrm{pH} 7.0$ ). The flask was incubated on a rotary shaker at $200 \mathrm{rpm}$ for $9 \sim 12 \mathrm{~h}$ at $28^{\circ} \mathrm{C}$. This fresh culture was inoculated to fermentation broth, each $2 \mathrm{ml}$. These flasks were incubated under the same conditions as described above for $48 \mathrm{~h}$. Culture supernatants
Table 1 Spectrum of antifungal activity

\begin{tabular}{cc}
\hline Plant pathogens & Inhibition zone $\mathbf{( m m})$ \\
\hline Fusarium oxysporum f.sp.cubense & $11.5 \mathrm{aA}$ \\
Corynespora cassiicola & $10.0 \mathrm{dD}$ \\
Alternaria solani & $12.1 \mathrm{bB}$ \\
Botrytis cinerea & $9.8 \mathrm{bBC}$ \\
Colletotrichum gloeosporioides & $18.3 \mathrm{dD}$ \\
Aspergillus niger & $12.3 \mathrm{bB}$ \\
\hline
\end{tabular}

Lowercase: $p=0.05$; Capital letter: $p=0.01$.

obtained after removed the cells by centrifugation at $6000 \mathrm{r} / \mathrm{min}$ for $20 \mathrm{~min}$ for further study.

The proteins were precipitated from the supernatant at $70 \%(\mathrm{w} / \mathrm{v})(\mathrm{NH} 4)_{2} \mathrm{SO}_{4}$ saturation. The latter was added in small portions with constant stirring for $30 \mathrm{~min}$. The stirring was continued for $1 \mathrm{~h}$, and the mixture was kept overnight at $4^{\circ} \mathrm{C}$. The precipitate was collected by centrifugation at $10000 \mathrm{r} / \mathrm{min}$ for $30 \mathrm{~min}$, dissolved in a $1 / 20(\mathrm{v} / \mathrm{v})$ phosphate buffer $(0.02 \mathrm{~mol} / \mathrm{L}, \mathrm{pH} 6.8)$, and dialyzed for $48 \mathrm{~h}$ with 8 changes in the same buffer (500 $\mathrm{ml} \mathrm{each}$ ) to remove ammonium sulfate. The dialysates were condensed to yield precipitated proteins, which were further purified by column chromatography. A part of the precipitated proteins were dissolved in phosphate buffer $(0.02 \mathrm{~mol} / \mathrm{L}, \mathrm{pH} 6.8)$, and the antifungal activity of the precipitated proteins was tested against Fusarium oxysporum by agar-diffusion method.

Chromatography was carried out on a DEAE-sepharose fast Flow ion exchange column previously equilibrated with $0.02 \mathrm{~mol} / \mathrm{L}$ phosphate buffer $(\mathrm{pH}$ 6.8). The column was eluted with $\mathrm{NaCl}$ in phosphate buffer $(0.02 \mathrm{~mol} / \mathrm{L}, \mathrm{pH} 6.8)$ to desorb the absorbed proteins (fractions I, II, III, IV). Each fraction was dialyzed in distilled water to remove $\mathrm{NaCl}$, and then adjusted to the same concentration with phosphate

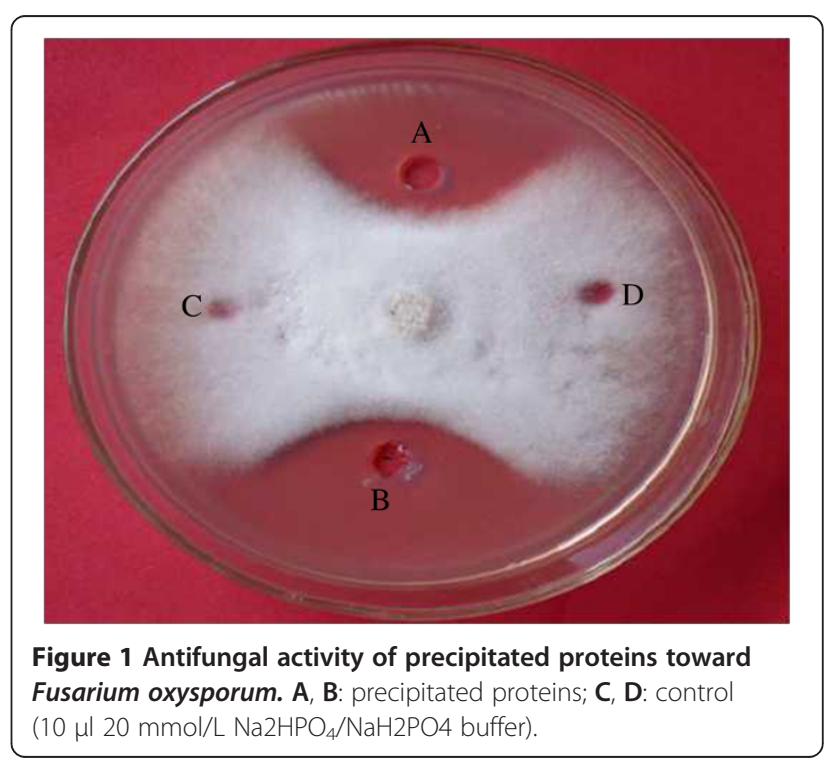




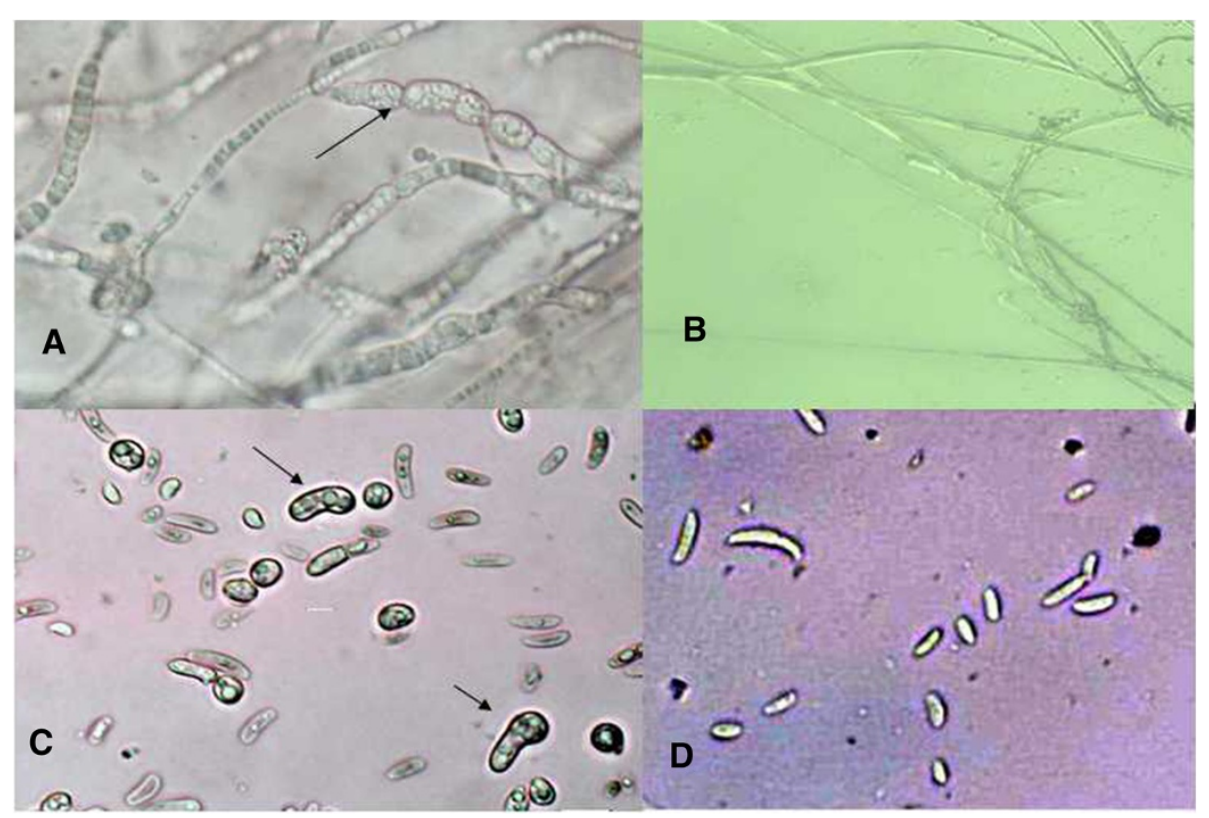

Figure 2 Function of the antifungal protein. A: Abnormal hypha appeared distorted, tumescent after treatment with; B: Normal hypha of FOC; C: Abnormal spores of FOC appeared distortion and tumescence after treatment with; D: Normal spore of F. oxysporum.

buffer. Anti-fungal activity was tested against Fusarium oxysporum by agar- diffusion method. Fraction III was subsequently chromatographed on SephadexG-100. The column was eluted with $0.02 \mathrm{~mol} / \mathrm{L}$ phosphate buffer $(\mathrm{pH} 6.8)$ to collect one main protein peak (P1) and another small protein peak (P2). The antifungal activity of the two fractions was tested. The protein concentration was determined using the method of Bradford (1976), with bovine serum albumin as a standard.

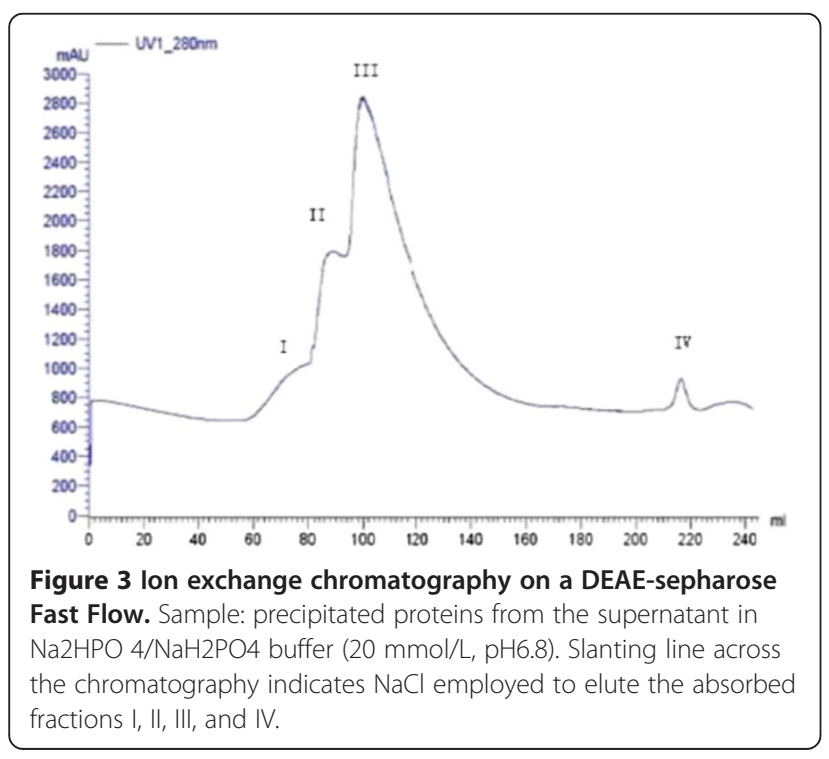

\section{NanoLC-ESI-MS/MS analysis}

The antifungal protein was separated by SDS-PAGE, analyzed by NanoLC-ESI-MS/MS, (ProtTech.Inc).

\section{Results}

\section{Spectrum of antifungal activity}

The antifungal spectra of B25 against FOC, Corynespora cassiicola, Alternaria solani, Botrytis cinerea, Colletotrichum gloeosporioides and Aspergillus niger, are shown in Table 1. The results indicated that B25 had a wide spectrum of antagonistic activities against plant pathogenic fungi.

\section{Antifungal activity of precipitated proteins}

Antifungal factor from B25 was further identified as a kind disease-resistance protein by ammonium sulfate precipitation method. The protein extracted could inhibit the pathogen in PDA (potato dextrose agar) medium and a clear zone of inhibition was observed between the protein and pathogen (Figure 1).

\section{Preliminary function of the antifungal protein}

Inhibitory effect of precipitated proteins on FOC as seen under the light microscope demonstrated that it had inhibitory effect on mycelia and spores. The disease-resistance protein caused distortion, tumescence of hyphae and spores (Figure 2).

\section{Isolation and purification of antifungal protein}

Ion exchange chromatography of B. subtilis B25 culture extract on a DEAE-sepharose. Fast Flow column contained 


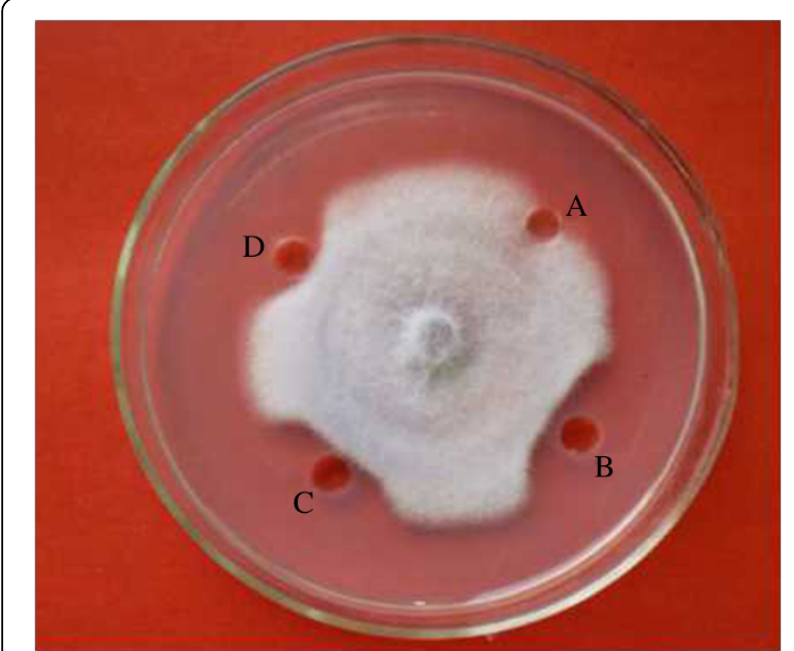

Figure 4 Antifungal activity of fractions from DEAE-sepharose Fast Flow and SephadexG-100 chromatographies toward Fusarium oxysporum. A: control $(10 \mu \mathrm{l} 20 \mathrm{mmol} / \mathrm{L} \mathrm{Na} 2 \mathrm{HPO}$ 4/NaH2PO4 buffer (PB buffer), pH 6.8); $\mathbf{B}$ : fraction III from DEAE-sepharose Fast Flow column chromatography; C: $20 \mu \mathrm{g}$ antifungal protein (fraction P1) in $10 \mu \mathrm{l} \mathrm{PB}$ buffer; D: $12 \mu \mathrm{g}$ antifungal protein (fraction P1) in $10 \mu \mathrm{l} \mathrm{PB}$ buffer.

one unabsorbed fraction and 4 adsorbed fractions (I, II, III, and IV) (Figure 3). Of these fractions, only fraction III showed strong antifungal activity (Figure 4), and fraction II showed a less antifungal activity. Fraction III was separated on the SephadexG-100 column into two fractions (P1 and P2) (Figure 5). Only fraction P1

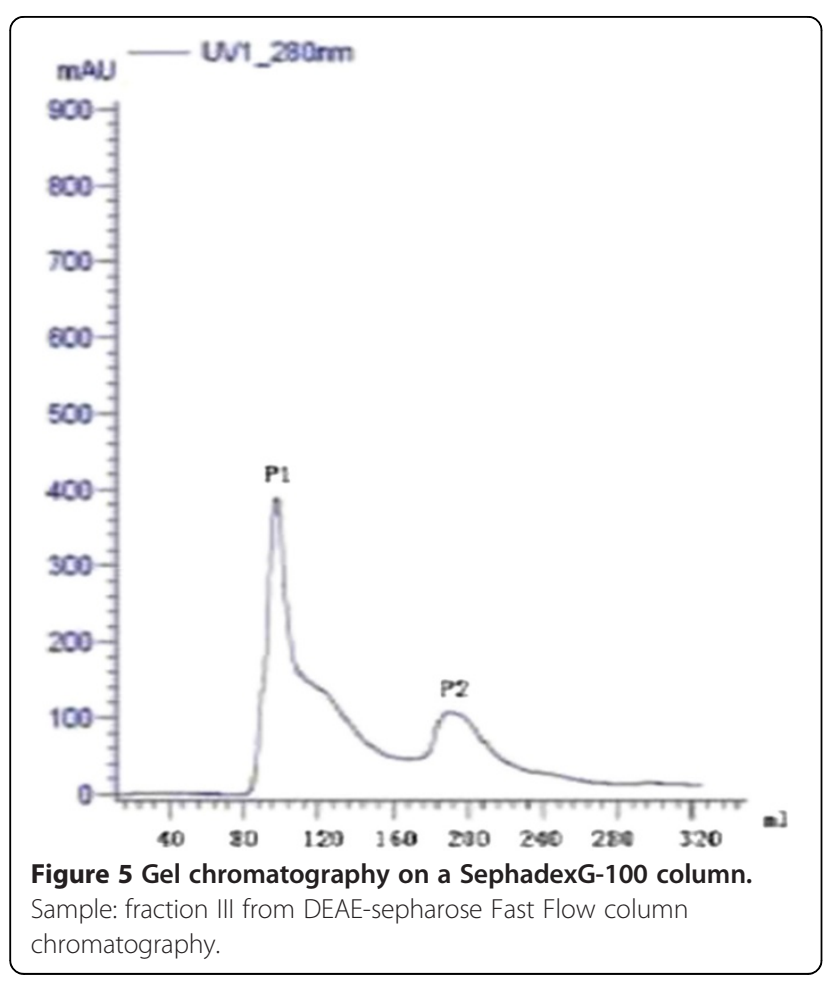

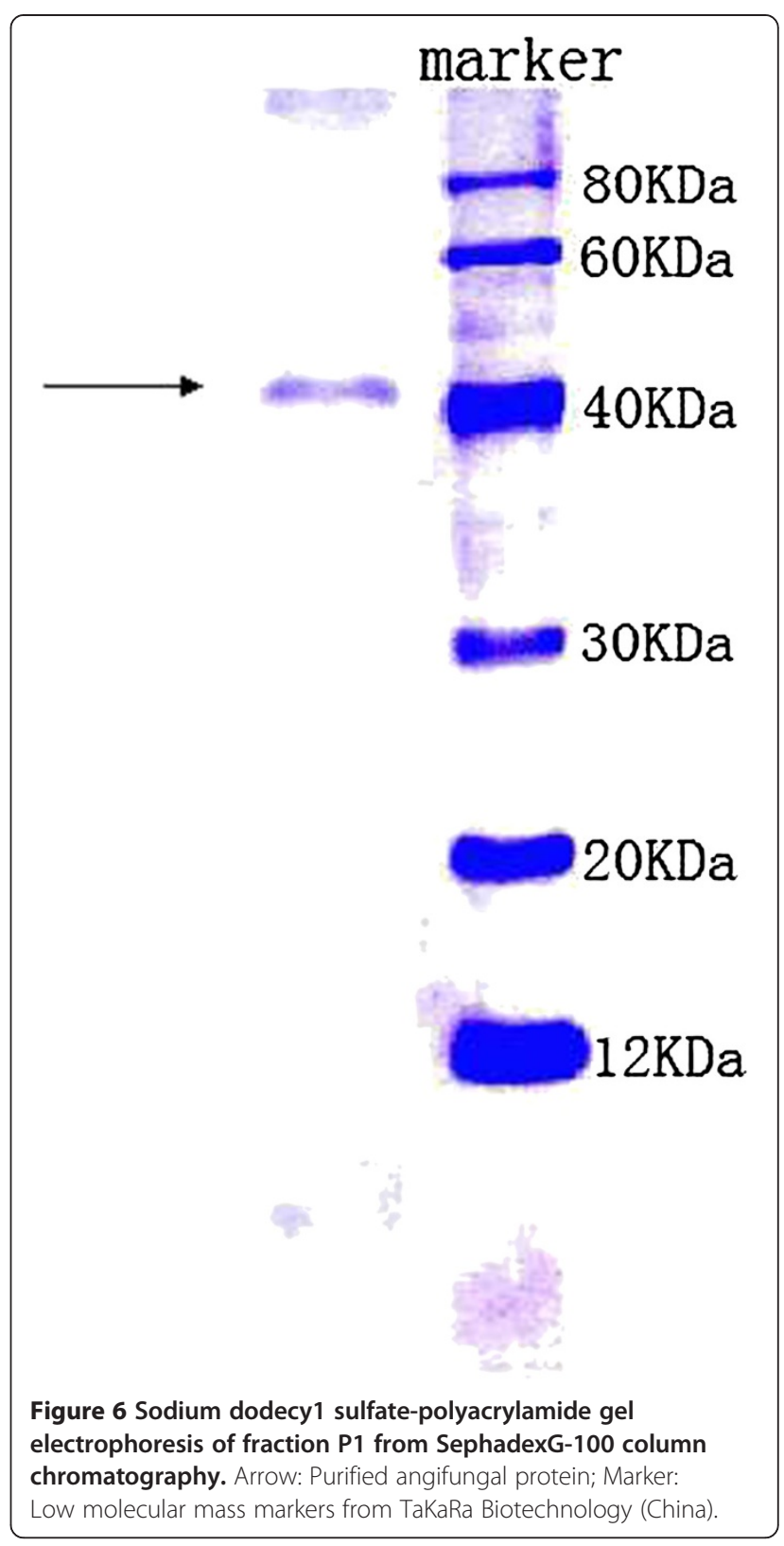

exhibited antifungal activity (Figure 4) and showed a single band in SDS-PAGE (Figure 6). The protein yields at various stages of chromatographic purification are shown in Table 2.

\section{Amino acid sequence analysis}

17 peptides were obtained by NanoLC-ESI-MS/MS. The amino acid sequences of 17 peptides segments were listed in Table 3. The protein mass was $38708.67 \mathrm{Da}$, and it's isoelectric point (pI) was 5.63. After searching the protein database of NCBI for the identity, we found that it was a hypothetical protein, which was derived from the genome of Bacillus amyloliquefaciens FZB42 
Table 2 Protein yields of chromatographic fractions with antifungal activity obtained at different stages of purification

\begin{tabular}{lll}
\hline Fraction & Total protein $(\mathbf{m g})$ & Recovery of protein (\%) \\
\hline Precipitated protein & 232.1 & 100.0 \\
$\begin{array}{l}\text { DEAE-sepharose Fast } \\
\text { Flowlll }\end{array}$ & 18.0 & 77.6 \\
SephadexG-100P1 & 15.3 & 85 \\
\hline
\end{tabular}

(gi 154685475). Except for the amino sequence, no any other information such as function, location, mass, and isoelectric point had ever been reported. Now, we found that it can be secreted by the bacteria, and acted on the plant fungi in the environment.

\section{Conclusion}

The growing awareness of preservation of the environment and health concerns drive the search for bio-safer and environmental friendly products than chemical pesticides. Increased concerns over the impact of chemicals on the environment have resulted in increase interest in biocontrol strategies. Biological control of Fusarium wilt by utilizing selected antagonistic bacteria might be an alternative approach.

The novel protein may be a potential biocontrol candidate and the report of it can supply additional literature on Bacillus subtilis antifungal proteins which control the fusarium wilt of banana. Further investigations of the nature and the structure, together with development of

Table 3 Peptides and their sequences

\begin{tabular}{lll}
\hline Scan no. & Peptide mass & Peptide sequence \\
\hline 3614 & 865.48 & HLAGLAER \\
3679 & 1247.64 & TKEETSDLGIR \\
3794 & 1305.61 & DASGPYHYQLR \\
3971 & 1225.67 & THELSLLNTAK \\
4005 & 1629.92 & KGGLFVTIPGRDDKK \\
4053 & 1501.82 & KGGLFVTIPGRDDK \\
4067 & 1978.00 & TYTGTILMHQTSVHVYK \\
4121 & 1373.73 & GGLFVTIPGRDDK \\
4130 & 1143.68 & KGGLFVTIPGR \\
4174 & 1467.81 & LLTAHVDTLGAMVK \\
4202 & 1151.56 & VGDFISFDPR \\
4252 & 2284.13 & SGHDIVHGLIGPGIDASHAFER \\
4256 & 2284.13 & SGHDIVHGLIGPGIDASHAFER \\
4334 & 1130.68 & LKIDLIGGFR \\
4653 & 1790.04 & HLDDKASVALLLNLIR \\
4672 & 1181.75 & ASVALLLNLIR \\
4777 & 2623.36 & ELVSIPSPTGNTYEVIAYTESLLK \\
\hline
\end{tabular}

suitable application, could have great potential for the control of plant pathogenic fungi.

\section{Discussion}

The molecular mass of it was not only larger than any other small antibiotic peptides, but also different from those of other reported antifungal proteins from $B$. subtilis, such as Bacisubin (41.9 kDa), protein from B.s G87 (50.8 kDa), protease $(41.38 \mathrm{kDa})$, bacillomycin $\mathrm{D}$ synthetase A $(448.21 \mathrm{kDa})$. Additionally, it was demonstrated neither protease, nor ribonuclease activity. And the protein has wide antifungal spectrum, which include plant pathogens and Aspergillus niger The action of the protein on the bacteria was not tested.

\section{Ethical standards}

All participants gave written informed consent. All authors have no dispute on the order of the writers.

\section{Competing interests}

This study was funded by Hainan Natural Science Foundation and Doctoral Science Foundation of Hainan University.

\section{Authors' contributions}

ZQT and RYZ made a substantial contribution to the conception and design of the study. BYL made a substantial contribution to the acquisition and analysis of the data. All authors had a hand in the preparation of this manuscript based on their interpretation of the data, and reviewed, approved and agreed upon the manuscript in its final format.

\section{Acknowledgments}

This work was supported by grants from Hainan Natural Science Foundation (80819), Doctoral Science Foundation of Hainan University.

Received: 14 July 2013 Accepted: 9 October 2013

Published: 17 October 2013

\section{References}

Bradford MM (1976) A rapid and sensitive method for the quantitation of microgram quantities of protein utilizing the principle of protein-dye binding. Anal Biochem 72:248-254

Carrillo C, Teruel JA, Aranda FJ, Ortiz A (2003) Molecular mechanism of membrane permeabilization by the peptide antibiotic surfactin. Biochim Biophys Acta 1611(1-2):91-97. doi:10.1016/S0005 -2736 (03)00029-4

Chen X, Li J, Sun Q, Tong Y, Xu J (2010) Isolation, purification and characterization of antifungal protein from rice endophytic bacterim Bacillus subtilis G87. Acta Microbiol Sinica 50:1353

Delcambe L, Peypoux F, Besson F, Guinand M, Michel G (1977) Structure of iturin and iturin-like substance. Biochem Society Transac 5(4):1122-1124

Lin BY (2013) Partial properties and purification of antifungal substance from Bacillus subtilis B25 strain. Master thesis of Hainan University, China, pp 1-51

Lin BY, Zhang RY, Tan ZQ (2013) Preliminary study of antimicrobial substance produced by Bacillus subtilis B25. Guangdong Agri Sci 1:82-84

Liu H (2011) Identification of antagonistic bacteria against banana wilt and its preliminary application. Master thesis of Hainan University, China, pp 1-50

Liu Y, Chen Z, Ng TB, Zhang J, Zhou M, Song F, Lu F (2007) Bacisubin, an antifungal protein with ribonuclease and hemagglutinating activities from Bacillus subtilis strain B-916. Peptides 28:553-559

Liu H, Tan ZQ, Zhang RY (2011) Identification of a Strain of Antagonistic Bacterium against Fusarium oxy sp orum f. sp. cubense and Control Experiment of Bagged Seedlings in vitro. China Southern Fruit 40(3):36-39

Loeffler W, Tschen JSM, Vanittanakom N, Kulger M, Knorpp E, Hsieh TF, Wu TG (1986) Antifungal effects of bacilysin and fengycin from Bacillus subtilis F29-3. A comparison with activities of other Bacillus an-tibiotics. J Phytopathol 115(3):204-213. doi:10.1111/j.1439-0434. 1986. tb00878.x 
Luo Y, Sun L, Zhu Z, Ran W, Shen Q (2013) Identification and characterization of an anti-fungi Fusarium oxysporum f. sp. cucumerium Protease from the Bacillus subtilis Strain N7. J Microbiol 51(3):359-366

Peypoux F, Besson F, Michel G (1980) Characterization oa new antibiotic of iturin group bacilloycin D. J Antibiot 33(10):1146-1149

Peypoux F, Pommier MT, Marion D, Ptak M, Das BC, Michel G (1986) Revised structure of mycosubtilin, a lipidolipid antibiotic from B. subtilis. J Antibiot 39(5):636-641

Peypoux F, Bonmatin JM, Wallach J (1999) Recent trends in the biochemistry of surfactin. Appl Microbiol Biotechnol 51(5):553-563. doi:10.1007/ s002530051432

Sengupta S, Banerjee AB, Bose SK (1971) $y$-Glutamyl and D- or L-peptide linkages in mycobacillin, a cyclic peptide antibiotic. Biochem J 121:839-846

Stein T (2005) Bacillus subtilis antibiotics: structure, syntheses and specific functions. Mol Microbiol 56:845-857

Tsuge K, Akiyama T, Shoda M (2001) Cloning, sequencing, and characterization of the iturin A operon. J Bacteriol 183(21):6265-6273. doi:10.1128/JB.183.21

doi:10.1186/2193-1801-2-543

Cite this article as: Tan et al:: A novel antifungal protein of Bacillus subtilis B25. SpringerPlus 2013 2:543.

\section{Submit your manuscript to a SpringerOpen ${ }^{\circ}$} journal and benefit from:

- Convenient online submission

- Rigorous peer review

- Immediate publication on acceptance

- Open access: articles freely available online

- High visibility within the field

- Retaining the copyright to your article

Submit your next manuscript at $\gg$ springeropen.com 